Int J Biochem Cell Biol. 2012 April ; 44(4): 573-577. doi:10.1016/j.biocel.2011.12.020.

\title{
Breast Cancer Stem Cells
}

\author{
Marco A. Velasco-Velázquez ${ }^{1,2}$, Nora Homsi ${ }^{1}$, Marisol De La Fuente ${ }^{3}$, and Richard G. \\ Pestell ${ }^{1}$ \\ ${ }^{1}$ Department of Cancer Biology, Kimmel Cancer Center, Thomas Jefferson University, \\ Philadelphia, PA, USA \\ 2Departamento de Farmacología, Facultad de Medicina, Universidad Nacional Autónoma de \\ México. Apdo. Postal 70-297, Ciudad Universitaria, México D.F. 04510, México \\ ${ }^{3}$ Shriners Hospitals Pediatric Research Center, School of Medicine, Temple University, \\ Philadelphia, PA, USA
}

\begin{abstract}
Breast cancer stem cells (BCSCs) constitute a subpopulation of tumor cells that express stem cellassociated markers and have a high capacity for tumor generation in vivo. Identification of BCSCs from tumor samples or breast cancer cell lines has been based mainly on $\mathrm{CD} 44^{+} / \mathrm{CD} 24^{-/ \mathrm{low}}$ or $\mathrm{ALDH}^{+}$phenotypes. BCSCs isolation has allowed the analysis of the molecular mechanisms involved in their origin, self-renewal, differentiation into tumor cells, resistance to radiation therapy and chemotherapy, and invasiveness and metastatic ability. Molecular genetic analysis using knockout animals and inducible transgenics have identified NF- кB, c-Jun, p21 ${ }^{\mathrm{CIP} 1}$, and Forkhead-like-protein Dach1 in BCSC expansion and fate. Clinical analyses of BCSCs in breast tumors have found a correlation between the proportion of BCSCs and poor prognosis. Therefore, new therapies that specifically target BCSCs are an urgent need. We summarize recent evidence that partially explain the biological characteristics of BCSCs.
\end{abstract}

\section{Keywords}

Breast cancer; cancer stem cell; metastasis; resistance; breast cancer therapy

\section{Introduction}

Cancer stem cells (CSCs) are tumor cells with enhanced capacity for tumor generation. CSCs possess several fundamental attributes similar to normal adult stem cells. They are capable of dividing asymmetrically to produce one stem cell, which enables the capacity for self-renewal, and one progenitor cell, which allows them to produce phenotypically diverse cancer cells that constitute tumors.

In 2003, Al-Hajj et al. made the initial discovery of breast CSCs (BCSCs) when he revealed a cellular population from human breast cancer tumors characterized by the cell-surface

(C) 2012 Elsevier Ltd. All rights reserved.

Corresponding author: Richard G. Pestell, M.D., Ph.D., Department of Cancer Biology, Thomas Jefferson University, 233 S. 10th Street, Philadelphia, PA 19107. Phone: 215-503-5692. Fax: 215-503-9334. richard.pestell@ jefferson.edu.

Reprints requests: Richard G. Pestell (richard.pestell@jefferson.edu) or Marco A. Velasco-Velazquez (marcovelasco@unam.mx)

Publisher's Disclaimer: This is a PDF file of an unedited manuscript that has been accepted for publication. As a service to our customers we are providing this early version of the manuscript. The manuscript will undergo copyediting, typesetting, and review of the resulting proof before it is published in its final citable form. Please note that during the production process errors may be discovered which could affect the content, and all legal disclaimers that apply to the journal pertain. 
markers $\mathrm{ESA}^{+} / \mathrm{CD} 44^{+} / \mathrm{CD} 24^{-/ \text {low }}$ and devoid of the expression of the lineage markers $\mathrm{CD} 2$, CD3, CD10, CD 16, CD18, CD31, CD64, and CD140b (Lin $\left.{ }^{-}\right)$. They found that the CD44 ${ }^{+}$ $\mathrm{CD} 24^{-/ l o w}$ subpopulation of $\mathrm{Lin}^{-}$cells in tumors was highly tumorigenic. As few as 200 $\mathrm{ESA}^{+} / \mathrm{CD} 44^{+} / \mathrm{CD} 24^{-/ \mathrm{low}}$ cells or $1000 \mathrm{CD} 44^{+} / \mathrm{CD} 24^{-/ l o w}$ cells, whether obtained from a primary site or metastatic pleural effusions, gave rise to tumors when xenotransplanted into NOD/SCID mice. In contrast, 50,000 unsorted cells were required to produce mouse tumors. The phenotypic heterogeneity of the initial tumor was conserved in tumors arising from injected CD $44^{+} / \mathrm{CD} 24^{-/ \mathrm{low}}$ cells. The tumors generated contained tumorigenic and nontumorigenic cells and portrayed diverse expression patterns of ESA, CD44, or CD24 (A1Hajj et al., 2003).

ALDH activity can also be used to enrich for BCSCs and normal mammary stem cells. $\mathrm{ALDH}^{+}$cells from human breast cancer tumors can be xenotransplanted into NOD/SCID mice and serially passaged in vivo, whereas $\mathrm{ALDH}^{-}$were unable to (Ginestier et al., 2007). Tumors generated by $\mathrm{ALDH}^{+}$cells show a phenotypic heterogeneity similar to that of the parental tumor, and tumor size and latency correlated with the number of $\mathrm{ALDH}^{+}$cells injected (Ginestier et al., 2007). The combination of $\mathrm{ALDH}^{+}$and $\mathrm{CD} 44^{+} / \mathrm{CD} 24^{-/ \mathrm{low}}$ phenotypes enriches further for cells with tumorigenic activity with as few as 20 of those cells capable of generating a tumor (Ginestier et al., 2007).

Even when other possible human BCSC markers have been identified (e.g. CD49f $\mathrm{f}^{+}$) the $\mathrm{CD} 44^{+} / \mathrm{CD} 24^{-/ \text {low }}$ and $\mathrm{ALDH}^{+}$phenotypes have been broadly used to identify breast cancer cells with increased tumorigenicity. Several groups have validated the stem cell phenotype of $\mathrm{CD} 44^{+} / \mathrm{CD} 24^{-/ \text {low }}$ or $\mathrm{ALDH}^{+}$cells. CD $44^{+} / \mathrm{CD} 24^{-/ \text {low }}$ cells express Oct- 4 , a common key marker for pluripotency and a putative stem cell marker, and overexpress genes associated with Hedgehog signaling, a pathway involved in self-renewal (Ponti et al., 2005, Shipitsin et al., 2007). Similarly, $\mathrm{ALDH}^{+}$population contains a number of upregulated stem cellassociated genes (Charafe-Jauffret et al., 2009). Finally, both CD $44^{+} / \mathrm{CD} 24^{-/ \text {low }}$ (Ponti et al., 2005) and $\mathrm{ALDH}^{+}$(Ginestier et al., 2007, Charafe-Jauffret et al., 2009) cells share with normal mammary stem/progenitor cells the ability to form mammospheres. Mammospheres are floating spherical colonies formed from a single cell in non-adherent culture. Since the ability of cancer cells to form mammospheres correlate with the ability of the mammosphere cells to induce tumors in SCID mice (Grimshaw et al., 2008, Ponti et al., 2005), mammosphere culture has been used to enrich for tumor-initiating cells. However, cells from mammospheres may encompass self-renewing cells together with cells lacking this property (Dey et al., 2009). Furthermore, it is not clear if cells from mammosphere cultures encompass an actual BCSC population or downstream progenitors, which have regained stem cell-like properties because of genetic alterations (Ponti et al., 2005). On the other hand, the number of colonies formed after mammosphere serial passage is an indirect measurement of self-renewal capacity.

\section{BCSCs Origin}

The origin of breast CSCs is controversial. Current experimental evidence supports two different, but not exclusive, theories (Fig. 1). One theory proposes that CSCs resulted from the deregulation of normal stem cell self-renewal and differentiation pathways, resulting in cancer cells with both self-renewal and differentiation capabilities. Evidence for this theory arises from the similarities between normal stem cells and CSCs and that normal stem cells are highly susceptible to mutations and oncogenic transformation due to their long lifespans (Ponti et al., 2005, Ginestier et al., 2007). Al-Hajj et al. believed that BCSCs are likely to originate from basal mammary stem/progenitor cells due to the similarities between the cell surface profile of basal cells and the putative BCSCs they discovered (Al-Hajj et al., 2003). 
A second theory suggests that BCSCs develop from epithelial-mesenchymal transition (EMT). Cells that have undergone EMT are susceptible to transformation and have many characteristics and behaviors similar to those of normal and neoplastic stem cells (Morel et al., 2008, Mani et al., 2008). CD44 /CD24//low cells from normal and carcinoma human breast tissues express many genes associated with cells that have undergone EMT (Mani et al., 2008). Furthermore, cells that have undergone an EMT formed 10-fold more mammospheres than did corresponding control cells, suggesting an increase in tumorigenicity in EMT-induced cells (Mani et al., 2008).

Ras-MAPK, Ras, c-Myc, p21 CIP1, TGF $\beta$, Wnt, Notch, NF- $\ltimes B$, EGF, HGF, FGF, and HIF signaling pathways are involved in EMT induction in cultured cells and in vivo (see (Thiery et al., 2009) for a recent review). In mammary epithelial cells, TGF $\beta$ signaling plays an important role. Ongoing autocrine signaling via the canonical and noncanonical Wnt pathways and the TGF $\beta$ pathway is responsible for inducing an EMT in normal and neoplastic human mammary epithelial cells (HMECs) and for maintaining their mesenchymal/CSC states (Scheel et al., 2011). TGF $\beta$ induces Pez, a tyrosine phosphatase, which in turn promotes EMT and TGF $\beta$ production, creating a positive autocrine feedback loop. Introduction of the Ras oncogene sensitize HMECs to EMT, and the addition of TGF $\beta 1$ accelerates this conversion, resulting in the appearance of tumorigenic CD44 ${ }^{+}$/ CD24-/low cells (Morel et al., 2008). The induction of EMT in the mammary gland in vivo or in isogenic human breast cancer cell lines by Ha-Ras or c-Myc, requires p21 ${ }^{\mathrm{CIP} 1}$ (Liu et al., 2009).

\section{Functions of BCSCs}

\section{A. Self-renewal and Differentiation}

BCSCs have the ability to self-renew and a potential to differentiate, generating cells with a variety of phenotypes within tumors. Several pathways have been implicated in the regulation of BCSC self-renewal, including Notch, Hedgehog, and Wnt. In addition, key transcription factors regulate BCSCs including NF- $\kappa \mathrm{B}$, c-Jun, the Forkhead-like-protein Dach1, and the CDK inhibitor p21 ${ }^{\text {CIP1 }}$ (Liu et al., 2010b, Jiao et al., 2010, Wu et al., 2011, Liu et al., 2009). In particular, in vitro and in vivo evidence revealed the importance of PTEN/PI3-K/Akt/Wnt/ $\beta$-catenin pathway in BCSC biology. PTEN knockdown in MCF-7 and SUM-159 cell lines induced activation of Akt, increased mammosphere formation, and increased the $\mathrm{ALDH}^{+}$population (Korkaya et al., 2009). When these cells were injected into NOD/SCID mice, increased Akt phosphorylation and tumorigenicity were observed, indicating that Akt regulates BCSC expansion (Korkaya et al., 2009). Active Akt phosphorylates GSK3 $\beta$ and thereby the Wnt pathway. Ongoing autocrine signaling via the Wnt pathway has been shown to regulate and maintain BCSC self-renewal (Scheel et al., 2011).

Another important feature of BSCSs is their ability to differentiate into non-stem breast cancer cells. This occurs in vivo (Al-Hajj et al., 2003, Ginestier et al., 2007) as well as under standard growth conditions (Iliopoulos et al., 2011). However it was unclear whether differentiated breast cancer cells could revert to stem cells. It has been shown that BCSCs can be derived from Ras-transformed CD44-/CD24+ HMECs (Morel et al., 2008) and mammalian differentiated epithelial cells (Chaffer et al., 2011). In agreement, IL-6 promotes the rapid generation of BCSCs from non-stem breast cancer cells (Iliopoulos et al., 2011), indicating that there is a dynamic plasticity between the two cell types, and suggesting that autocrine cytokine microenvironmental signals participate in its control.

Retinoic acid, which is oxidized from retinol by ALDH, plays a role in the control of selfrenewal vs. differentiation of BCSCs. ATRA, an inducer of retinoid signaling, decreases 
mammosphere formation and either induces genes expressed in differentiated breast cancer cells or dowregulates several programs involved in BCSC self-renewal (the polycomb EZH2 network, Wnt signaling, Akt/ $\beta$-catenin signaling) (Ginestier et al., 2009). These results suggest that ALDH activity and retinoid signaling regulates the BCSC population by promoting differentiation and highlights the possible therapeutic application of compounds (ATRA or others) that force the differentiation of BCSC.

\section{B. Therapy resistance}

BCSCs demonstrate resistance to chemo- and radiotherapy. Administration of neoadjuvant chemotherapy to breast cancer patients increases the fraction of CD44 $/ \mathrm{CD} 24^{-/ l o w}$ tumor cells and augments mammosphere formation in vitro (Yu et al., 2007). Similarly, paclitaxel and epirubicin-based chemotherapy enriches for $\mathrm{ALDH}^{+}$cells in breast tumors (Tanei et al., 2009). Enrichment of BCSCs by chemotherapy and radiotherapy has also been reported in mouse and in vitro models. Tumors generated by consecutive passage of human breast cancer cells into mice receiving epirubicin were highly enriched in CD $44^{+} / \mathrm{CD} 24^{-/ \text {low }}$ cells (Yu et al., 2007). Radiation therapy also increases the CD44 $/$ CD24-/low proportion in mouse xenografts (Zielske et al., 2011, Phillips et al., 2006).

Drug resistance in BCSCs is associated with alterations in self-renewal and cell fate signaling pathways, including Notch, Wnt, Hedgehog, and HER-2. For example, Notch-1 overexpression is associated with chemoresistance (Sajithlal et al., 2010) and radioresistance (Phillips et al., 2006) of BCSCs. These effects may be mediated in part by the ability of Notch to promote the antiapoptotic gene survivin or the induction of cyclin D1 by Notch (Stahl et al., 2006). Increased survivin levels deregulate multiple mitotic checkpoints, contributing to genetic instability and inhibiting radiation- and drug-induced apoptosis (Phillips et al., 2006, Ponti et al., 2005, Sajithlal et al., 2010). Cyclin D1 is required for selfrenewal of normal and cancer mammary stem cells (Jeselsohn et al., 2010) and is indispensable Notch1-induced mammary tumorigenesis (Ling et al., 2010). Cyclin D1 enhances Notch1 activity by inhibiting the expression of its negative regulator Numb (Lindsay et al., 2008). Since cyclin D1 is also a downstream target of Wnt, Stat3, $\beta$-catenin, and NF- $\mathrm{kB}$ signaling, it may be an important target governing stem cell expansion (VelascoVelazquez et al., 2011a).

Given their tumorigenic properties and increased resistance to therapy, BCSCs have been implicated in therapeutic relapse. The BCSCs that survived the selective pressure exerted by therapy may pass on reduced sensitivity to their progeny, promoting the appearance of clinical resistance and allowing evolution of a more aggressive tumor over time (Fig. 2). However, that resistance is not a universal characteristic of BCSCs. BCSC population within a triple (estrogen receptor (ER), progesterone receptor (PR) and HER-2) negative cell line can be depleted by radiotherapy, supporting the hypothesis that resistance in not an intrinsic feature of BCSCs and suggesting a role for the molecular phenotype of the tumor (Zielske et al., 2011). Elucidation of the molecular mechanisms by which CSCs survive (or do not) survive therapy may identify new targets for breast cancer therapeutic intervention.

\section{Metastasis}

The cancer stem cell hypothesis considers that only CSCs will initiate and sustain tumor growth. In such model, CSCs are responsible for the metastatic dissemination of tumors. Different lines of evidence indicate that BCSCs play an important role in metastasis (reviewed by (Velasco-Velazquez et al., 2011b)). BCSCs display increased cell motility, invasion, and overexpress genes that promote metastasis (Liu et al., 2010a, Shipitsin et al., 2007, Charafe-Jauffret et al., 2009). Intracardiac injection of $\mathrm{ALDH}^{+}$breast cancer cells, but not unseparated or $\mathrm{ALDH}^{-}$cells, into immunodeficient mice, generates multiple metastases 
that recapitulate the heterogeneity of the initial tumor (Charafe-Jauffret et al., 2009, CharafeJauffret et al., 2010). Mammary fat pad implantation of CD44 $/$ CD24 $4^{-/ \text {low }}$ cells from human breast tumor samples produces spontaneous lung metastasis that can be serially passaged (Liu et al., 2010a).

These results support the idea that the metastatic population of breast cancer cells is contained within the BCSCs. However, it remains to be determined whether there is a subset of metastatic BCSCs with unique metastatic properties, what the specific phenotype is, and if those characteristics are constant among the different molecular subtypes of breast cancer.

\section{Clinical importance}

The role of BCSCs in the clinical outcome of breast cancer patients has been analyzed using different strategies. The gene-expression profile of $\mathrm{CD} 44^{+} / \mathrm{CD} 24^{-/ \text {low }}$ breast cancer cells compared with normal breast epithelium identified a gene signature that is strongly associated with metastasis-free survival (Liu et al., 2007). Combined immunohistochemical analysis of CD44 and CD24 in breast tumor samples identified a correlation between a high percentage of $\mathrm{CD} 44^{+} / \mathrm{CD} 24^{-/ \mathrm{low}}$ tumor cells in primary tumors and the presence of distant metastasis, particularly osseous metastases (Abraham et al., 2005). Pleural metastases from breast cancer patients that received chemotherapy are highly enriched for a $\mathrm{CD} 44^{+} /$ CD24-/low subpopulation (Yu et al., 2007), suggesting that chemoresistance of BCSCs may be associated with metastasis formation. ALDH expression in human breast cancer samples correlates significantly with tumor grade, metastasis and cancer stage, and decreased survival (Charafe-Jauffret et al., 2010, Marcato et al., 2011). Since the isoform ALDH1A3 is the main responsible for ALDH activity in BCSCs, quantification of its expression may be a better prognostic marker in breast tumor samples (Marcato et al., 2011).

Although the presence of BCSC markers correlates with poor prognosis in clinical samples, the contribution of non-stem cancer cells to the clinical outcome cannot be underestimated. For example, cancer cells other than BCSCs can form metastasis in vivo or in experimental models, indicating that cells with an invasive phenotype can be found outside the BCSC pool. Additionally, the precise role of BCSCs in tumor progression still remains to be determined. At present it is unknown if BCSC population can be further subdivided and whether such subsets have unique tumorigenic, metastatic, or resistance properties. Finally, stem-like properties of cancer cells can change in different microenvironments, suggesting that the models used for study of BCSC may not reflect the clinical setting.

Since the association between BCSCs prevalence and clinical outcome and the evidence presented above support key roles of BCSCs in breast cancer biology, it has been proposed that new therapies must target these cells. For this goal, different strategies have been evaluated, including targeting of membrane markers and transporters, interruption of intracellular signaling pathways, and alteration of the BCSCs microenvironment. Despite the success of some of those therapies in preclinical models, toxicology and pharmacokinetic studies are still required before human tests. For example, high-throughput screening identified the ionophore salinomycin as toxic to BCSCs (Gupta et al., 2009). However, salinomycin has produced adverse effects in non-rodent preclinical models. Nevertheless, the methodology used by Gupta and collaborators (Gupta et al., 2009) could lead to the finding of new BCSCs-targeting drugs.

Serendipitously, several drugs tested clinically for other applications have shown activity against BCSCs. Recent studies showed that the anti-diabetic drug metformin selectively reduces the $\mathrm{CD} 44^{+} / \mathrm{CD} 24^{-/ l o w}$ population and the ability to form mammospheres (Hirsch et al., 2009). In a xenograft mice models, concurrent treatment with metformin and chemotherapeutic agents reduced tumor mass much more effectively than either drug alone 
and prevents relapse (Hirsch et al., 2009). Metformin effects on BCSCs may be mediated by AMP-activated kinase (AMPK) activation and the consequent inhibition of Acetyl CoA carboxylase (ACACA) and associated alterations in fatty acid synthesis and functioning of lipid raft plataforms.

The anti-immflamatory drug repertaxin, an antagonist of the IL-8 receptor CXCR1, reduced the BCSC population, producing apotosis in the tumor population, and reduced metastasis in mouse models (Ginestier et al., 2010), indicating that interruption of signals generated in the microenvironment may be useful for BCSC eradication.

\section{Acknowledgments}

This work was supported in part by the following NIH grants R01CA070896, R01CA075503, R01CA107382, R01CA132115, and R01CA086072 (R.G.P.). The Kimmel Cancer Center was supported by the NIH Cancer Center Core Grant P30CA56036 (to R.G.P.). This project is funded in part from the Marian C. Falk Medical Research Trust and a grant from the Pennsylvania Department of Health (R.G.P.).

\section{References}

Abraham BK, Fritz P, McClellan M, Hauptvogel P, Athelogou M, Brauch H. Prevalence of CD44+/ CD24-/low cells in breast cancer may not be associated with clinical outcome but may favor distant metastasis. Clin Cancer Res. 2005; 11:1154-1159. [PubMed: 15709183]

Al-Hajj M, Wicha MS, Benito-Hernandez A, Morrison SJ, Clarke MF. Prospective identification of tumorigenic breast cancer cells. Proc Natl Acad Sci U S A. 2003; 100:3983-3988. [PubMed: 12629218]

Chaffer CL, Brueckmann I, Scheel C, Kaestli AJ, Wiggins PA, Rodrigues LO, Brooks M, Reinhardt F, $\mathrm{Su}$ Y, Polyak K, Arendt LM, Kuperwasser C, Bierie B, Weinberg RA. Normal and neoplastic nonstem cells can spontaneously convert to a stem-like state. Proc Natl Acad Sci U S A. 2011; 108:7950-7955. [PubMed: 21498687]

Charafe-Jauffret E, Ginestier C, Iovino F, Tarpin C, Diebel M, Esterni B, Houvenaeghel G, Extra JM, Bertucci F, Jacquemier J, Xerri L, Dontu G, Stassi G, Xiao Y, Barsky SH, Birnbaum D, Viens P, Wicha MS. Aldehyde dehydrogenase 1-positive cancer stem cells mediate metastasis and poor clinical outcome in inflammatory breast cancer. Clin Cancer Res. 2010; 16:45-55. [PubMed: 20028757]

Charafe-Jauffret E, Ginestier C, Iovino F, Wicinski J, Cervera N, Finetti P, Hur MH, Diebel ME, Monville F, Dutcher J, Brown M, Viens P, Xerri L, Bertucci F, Stassi G, Dontu G, Birnbaum D, Wicha MS. Breast cancer cell lines contain functional cancer stem cells with metastatic capacity and a distinct molecular signature. Cancer Res. 2009; 69:1302-1313. [PubMed: 19190339]

Dey D, Saxena M, Paranjape AN, Krishnan V, Giraddi R, Kumar MV, Mukherjee G, Rangarajan A. Phenotypic and functional characterization of human mammary stem/progenitor cells in long term culture. PLoS One. 2009; 4:e5329. [PubMed: 19390630]

Ginestier C, Hur MH, Charafe-Jauffret E, Monville F, Dutcher J, Brown M, Jacquemier J, Viens P, Kleer CG, Liu S, Schott A, Hayes D, Birnbaum D, Wicha MS, Dontu G. ALDH1 is a marker of normal and malignant human mammary stem cells and a predictor of poor clinical outcome. Cell Stem Cell. 2007; 1:555-567. [PubMed: 18371393]

Ginestier C, Liu S, Diebel ME, Korkaya H, Luo M, Brown M, Wicinski J, Cabaud O, Charafe-Jauffret E, Birnbaum D, Guan JL, Dontu G, Wicha MS. CXCR1 blockade selectively targets human breast cancer stem cells in vitro and in xenografts. J Clin Invest. 2010; 120:485-497. [PubMed: 20051626]

Ginestier C, Wicinski J, Cervera N, Monville F, Finetti P, Bertucci F, Wicha MS, Birnbaum D, Charafe-Jauffret E. Retinoid signaling regulates breast cancer stem cell differentiation. Cell Cycle. 2009; 8:3297-3302. [PubMed: 19806016]

Grimshaw MJ, Cooper L, Papazisis K, Coleman JA, Bohnenkamp HR, Chiapero-Stanke L, TaylorPapadimitriou J, Burchell JM. Mammosphere culture of metastatic breast cancer cells enriches for tumorigenic breast cancer cells. Breast Cancer Res. 2008; 10:R52. [PubMed: 18541018] 
Gupta PB, Onder TT, Jiang G, Tao K, Kuperwasser C, Weinberg RA, Lander ES. Identification of selective inhibitors of cancer stem cells by high-throughput screening. Cell. 2009; 138:645-659. [PubMed: 19682730]

Hirsch HA, Iliopoulos D, Tsichlis PN, Struhl K. Metformin selectively targets cancer stem cells, and acts together with chemotherapy to block tumor growth and prolong remission. Cancer Res. 2009; 69:7507-7511. [PubMed: 19752085]

Iliopoulos D, Hirsch HA, Wang G, Struhl K. Inducible formation of breast cancer stem cells and their dynamic equilibrium with non-stem cancer cells via IL6 secretion. Proc Natl Acad Sci U S A. 2011; 108:1397-1402. [PubMed: 21220315]

Jeselsohn R, Brown NE, Arendt L, Klebba I, Hu MG, Kuperwasser C, Hinds PW. Cyclin D1 kinase activity is required for the self-renewal of mammary stem and progenitor cells that are targets of MMTV-ErbB2 tumorigenesis. Cancer Cell. 2010; 17:65-76. [PubMed: 20129248]

Jiao X, Katiyar S, Willmarth NE, Liu M, Ma X, Flomenberg N, Lisanti MP, Pestell RG. c-Jun induces mammary epithelial cellular invasion and breast cancer stem cell expansion. J Biol Chem. 2010; 285:8218-8226. [PubMed: 20053993]

Korkaya H, Paulson A, Charafe-Jauffret E, Ginestier C, Brown M, Dutcher J, Clouthier SG, Wicha MS. Regulation of mammary stem/progenitor cells by PTEN/Akt/beta-catenin signaling. PLoS Biol. 2009; 7:e1000121. [PubMed: 19492080]

Lindsay J, Jiao X, Sakamaki T, Casimiro MC, Shirley LA, Tran TH, Ju X, Liu M, Li Z, Wang C, Katiyar S, Rao M, Allen KG, Glazer RI, Ge C, Stanley P, Lisanti MP, Rui H, Pestell RG. ErbB2 induces Notch1 activity and function in breast cancer cells. Clin Transl Sci. 2008; 1:107-115. [PubMed: 20443831]

Ling H, Sylvestre JR, Jolicoeur P. Notch1-induced mammary tumor development is cyclin D1dependent and correlates with expansion of pre-malignant multipotent duct-limited progenitors. Oncogene. 2010; 29:4543-4554. [PubMed: 20562911]

Liu H, Patel MR, Prescher JA, Patsialou A, Qian D, Lin J, Wen S, Chang YF, Bachmann MH, Shimono Y, Dalerba P, Adorno M, Lobo N, Bueno J, Dirbas FM, Goswami S, Somlo G, Condeelis J, Contag CH, Gambhir SS, Clarke MF. Cancer stem cells from human breast tumors are involved in spontaneous metastases in orthotopic mouse models. Proc Natl Acad Sci U S A. 2010a; 107:18115-18120. [PubMed: 20921380]

Liu M, Casimiro MC, Wang C, Shirley LA, Jiao X, Katiyar S, Ju X, Li Z, Yu Z, Zhou J, Johnson M, Fortina P, Hyslop T, Windle JJ, Pestell RG. p21CIP1 attenuates Ras- and c-Myc-dependent breast tumor epithelial mesenchymal transition and cancer stem cell-like gene expression in vivo. Proc Natl Acad Sci U S A. 2009; 106:19035-19039. [PubMed: 19858489]

Liu M, Sakamaki T, Casimiro MC, Willmarth NE, Quong AA, Ju X, Ojeifo J, Jiao X, Yeow WS, Katiyar S, Shirley LA, Joyce D, Lisanti MP, Albanese C, Pestell RG. The canonical NF-kappaB pathway governs mammary tumorigenesis in transgenic mice and tumor stem cell expansion. Cancer Res. 2010b; 70:10464-10473. [PubMed: 21159656]

Liu R, Wang X, Chen GY, Dalerba P, Gurney A, Hoey T, Sherlock G, Lewicki J, Shedden K, Clarke MF. The prognostic role of a gene signature from tumorigenic breast-cancer cells. N Engl J Med. 2007; 356:217-226. [PubMed: 17229949]

Mani SA, Guo W, Liao MJ, Eaton EN, Ayyanan A, Zhou AY, Brooks M, Reinhard F, Zhang CC, Shipitsin M, Campbell LL, Polyak K, Brisken C, Yang J, Weinberg RA. The epithelialmesenchymal transition generates cells with properties of stem cells. Cell. 2008; 133:704-715. [PubMed: 18485877]

Marcato P, Dean CA, Pan D, Araslanova R, Gillis M, Joshi M, Helyer L, Pan L, Leidal A, Gujar S, Giacomantonio CA, Lee PW. Aldehyde Dehydrogenase Activity of Breast Cancer Stem Cells is Primarily Due to Isoform ALDH1A3 and Its Expression is Predictive of Metastasis. Stem Cells. 2011; 29:32-45. [PubMed: 21280157]

Morel AP, Lievre M, Thomas C, Hinkal G, Ansieau S, Puisieux A. Generation of breast cancer stem cells through epithelial-mesenchymal transition. PLoS ONE. 2008; 3:e2888. [PubMed: 18682804]

Phillips TM, McBride WH, Pajonk F. The response of CD24(-/low)/CD44+ breast cancer-initiating cells to radiation. J Natl Cancer Inst. 2006; 98:1777-1785. [PubMed: 17179479] 
Ponti D, Costa A, Zaffaroni N, Pratesi G, Petrangolini G, Coradini D, Pilotti S, Pierotti MA, Daidone MG. Isolation and in vitro propagation of tumorigenic breast cancer cells with stem/progenitor cell properties. Cancer Res. 2005; 65:5506-5511. [PubMed: 15994920]

Sajithlal GB, Rothermund K, Zhang F, Dabbs DJ, Latimer JJ, Grant SG, Prochownik EV. Permanently blocked stem cells derived from breast cancer cell lines. Stem Cells. 2010; 28:1008-1018. [PubMed: 20506227]

Scheel C, Eaton EN, Li SH, Chaffer CL, Reinhardt F, Kah KJ, Bell G, Guo W, Rubin J, Richardson AL, Weinberg RA. Paracrine and autocrine signals induce and maintain mesenchymal and stem cell states in the breast. Cell. 2011; 145:926-940. [PubMed: 21663795]

Shipitsin M, Campbell LL, Argani P, Weremowicz S, Bloushtain-Qimron N, Yao J, Nikolskaya T, Serebryiskaya T, Beroukhim R, Hu M, Halushka MK, Sukumar S, Parker LM, Anderson KS, Harris LN, Garber JE, Richardson AL, Schnitt SJ, Nikolsky Y, Gelman RS, Polyak K. Molecular definition of breast tumor heterogeneity. Cancer Cell. 2007; 11:259-273. [PubMed: 17349583]

Stahl M, Ge C, Shi S, Pestell RG, Stanley P. Notch1-induced transformation of RKE-1 cells requires up-regulation of cyclin D1. Cancer Res. 2006; 66:7562-7570. [PubMed: 16885355]

Tanei T, Morimoto K, Shimazu K, Kim SJ, Tanji Y, Taguchi T, Tamaki Y, Noguchi S. Association of breast cancer stem cells identified by aldehyde dehydrogenase 1 expression with resistance to sequential Paclitaxel and epirubicin-based chemotherapy for breast cancers. Clin Cancer Res. 2009; 15:4234-4241. [PubMed: 19509181]

Thiery JP, Acloque H, Huang RY, Nieto MA. Epithelial-mesenchymal transitions in development and disease. Cell. 2009; 139:871-890. [PubMed: 19945376]

Velasco-Velazquez MA, Li Z, Casimiro M, Loro E, Homsi N, Pestell RG. Examining the role of cyclin D1 in breast cancer. Future Oncol. 2011a; 7:753-765. [PubMed: 21675838]

Velasco-Velazquez MA, Popov VM, Lisanti MP, Pestell RG. The role of breast cancer stem cells in metastasis and therapeutic implications. Am J Pathol. 2011b; 179:2-11. [PubMed: 21640330]

Wu K, Jiao X, Li Z, Katiyar S, Casimiro MC, Yang W, Zhang Q, Willmarth NE, Chepelev I, Crosariol M, Wei Z, Li A, Zhao J, Pestell RG. The cell fate determination factor dachshund reprograms breast cancer stem cell function. J Biol Chem. 2011; 286:2132-2142. [PubMed: 20937839]

Yu F, Yao H, Zhu P, Zhang X, Pan Q, Gong C, Huang Y, Hu X, Su F, Lieberman J, Song E. let-7 regulates self renewal and tumorigenicity of breast cancer cells. Cell. 2007; 131:1109-1123. [PubMed: 18083101]

Zielske SP, Spalding AC, Wicha MS, Lawrence TS. Ablation of breast cancer stem cells with radiation. Transl Oncol. 2011; 4:227-233. [PubMed: 21804918] 


\section{Key Facts}

- Breast cancer stem cells (BCSCs) comprise a small subpopulation within tumors with increased tumorigenicity in xenograft models.

- BCSCs are capable of self-renewal and differentiation.

- BCSCs express genes and display activated cell signaling pathways associated with normal stem cells.

- Human BCSCs can be identified by the expression of specific phenotypes, being most frequently $\mathrm{CD} 44^{+} / \mathrm{CD} 24^{-/ \text {low }}$ and $\mathrm{ALDH}^{+}$.

- BCSC display increased resistance against radiation and chemotherapy, pointing to the need for new therapeutic regimens that target these cells.

- BCSCs are more invasive in vitro and more metastatic in vivo and may contribute to clinical metastases. 


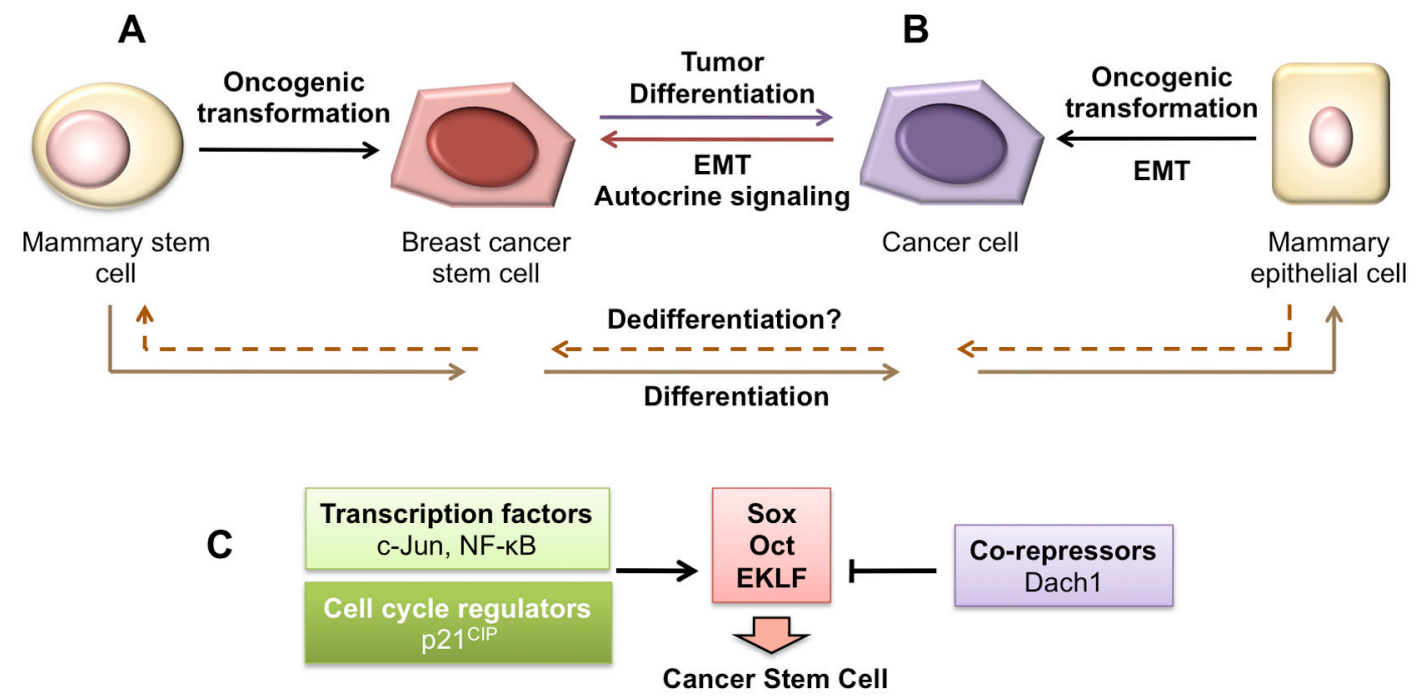

Figure 1. Origin of the breast cancer stem cells (BCSCs)

BCSCs may arise from normal mammary stem cells (A) or from non-stem tumor cells that have gained the ability for self-renewal (B) by epithelial to mesenchymal transition (EMT) and oncogenic transformation. Both of these hypotheses consider that the phenotypic characteristics of BCSCs are caused by genetic alterations and/or EMT. As result, BCSCs display alterations in signaling pathways controlling the cell cycle, differentiation, and survival (C). 

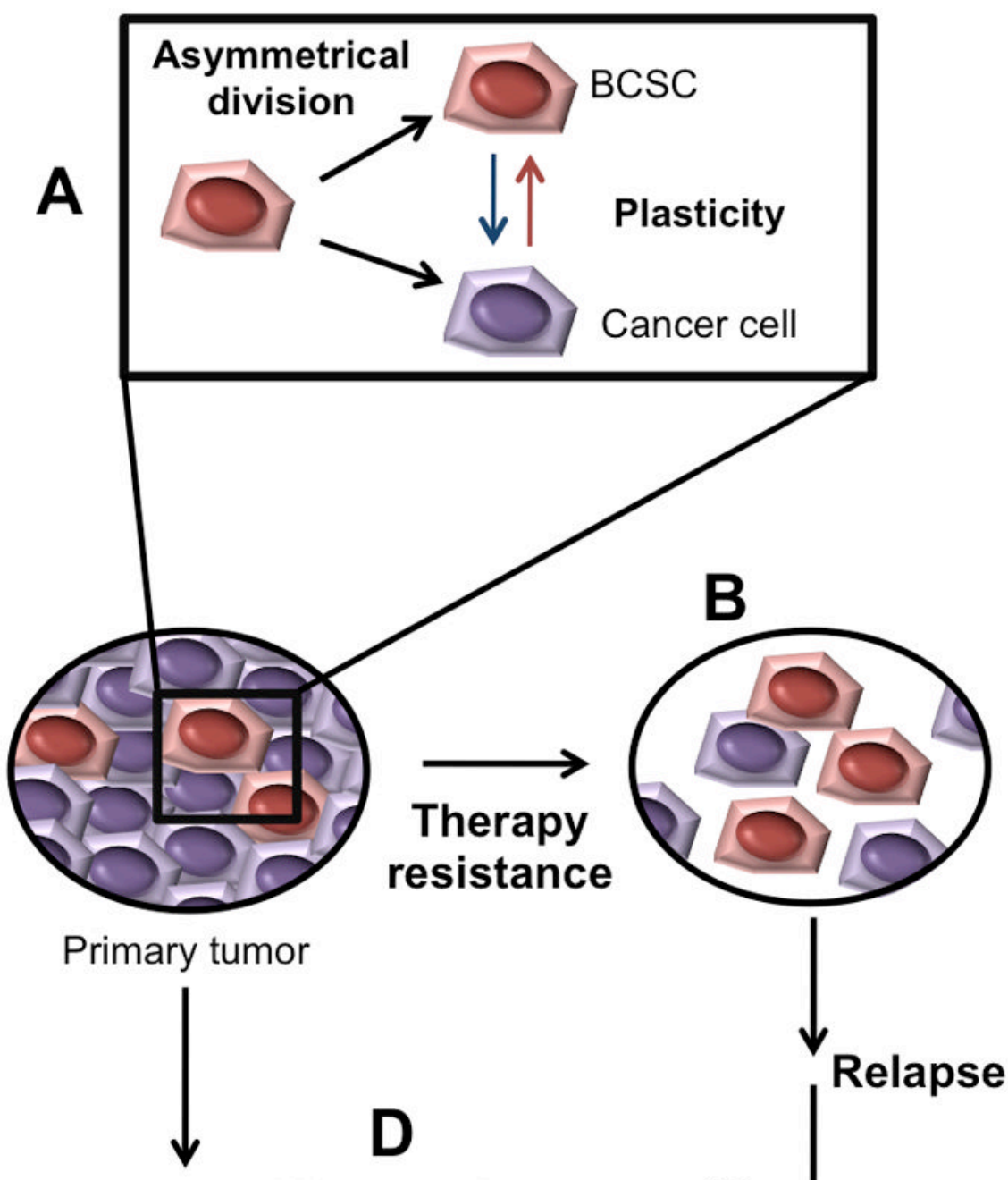

D
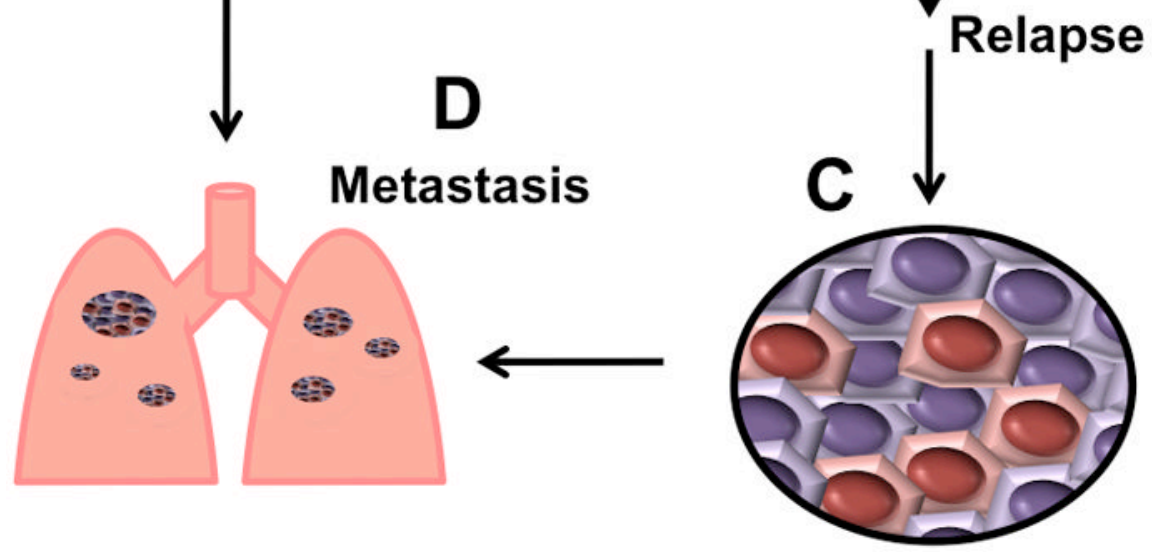

Figure 2. Key roles of breast cancer stem cells (BCSCs) in disease's progression The small fraction of BCSCs within tumors is maintained by self-renewal of BCSCs and by "dedifferentiation" of cancer cells (A). BCSCs are more resistant to radiation and chemotherapy than the rest of tumor cells and can survive therapy (B). The surviving CSCs will be capable to repopulate treated-tumors and produce relapse $(\mathrm{C})$. BCSCs can also be the source of metastastic lesions (D). 